\title{
Subclinical tubular epithelium damage and acute kidney injury following allogeneic hematopoietic stem cell transplantation
}

\author{
Vladimir A. Dobronravov ${ }^{1,2}$, Kirill A. Smirnov ${ }^{1,2}$, Boris V. Afanasiev ${ }^{1,3}$, Olga V. Galkina ${ }^{1,2}$, Alexey V. Smirnov ${ }^{1,2}$ \\ Prof. Vladimir A. Dobronravov, MD, PhD, DSc, Research Institute of Nephrology, The First St. Petersburg I. Pavlov State \\ Medical University, Russia, L.Tolstoy St. 17, 197089, St. Petersburg, Russia
}

${ }^{1}$ First St. Petersburg I. Pavlov State Medical University, Russia,

${ }^{2}$ Nephrology Research Institute,

${ }^{3}$ Raisa Gorbacheva Memorial Research Institute of Children Oncology, Hematology and Transplantation, St. Petersburg, Russia

\section{Summary}

The aim of this study was to determine clinical value of molecular biomarkers (MBM), associated with tubular epithelium damage, for the prediction of acute kidney injury (AKI) in the setting of hematopoietic stem cell transplantation (HSCT).

\section{Patients and methods}

Ninety HSCT recipients (46 males, 44 females) were enrolled into the observational prospective study. Urinary concentrations of calbindin, clusterin, IL-18 (interleukin-18), KIM-1 (kidney injury molecule-1), GST- $\pi$ (glutathione S-transferase- $\pi$ ) and MCP-1 (monocyte chemoattractant protein-1) were measured in all patients before HSCT and at 5 consequent time points during early post-transplant period, along with routine clinical monitoring. AKI was defined according to the KDIGO (Kidney Disease Improving Global Outcomes) Guidelines.

\section{Introduction}

Acute kidney injury (AKI), being a common complication of various conditions, is associated with high mortality and became a substantial challenge for modern medicine [23]. AKI is known to be a risk factor for development and progression of chronic kidney disease (CKD) that represents serious medical and social problem [7]. Conventional criteria for AKI di-

\section{Results}

The incidence of AKI cases constantly increased during the observation period and reached the maximum level by the week 5 following HSCT. MBM elevation was observed more frequently than AKI and preceded the latter. Clusterin, MCP-1 and KIM-1 levels significantly correlated with subsequent serum creatinine values, measured a week after the MBM's analysis according to multivariate linear regression models adjusted for other confounders. An increase in KIM-1 and/or MCP-1 urinary excretion was independently associated with a relative risk of AKI development. In summary, multiple renotoxic events early after HSCT commonly result in markedly increased urinary excretion of distinct molecular biomarkers, reflecting subclinical tubular injury in the absence of AKI criteria. The subsequent development of AKI can be predicted by means of KIM-1 and MCP-1 urinary excretion evaluation.

\section{Keywords}

Acute kidney injury, hematopoietic stem cell transplantation, biomarkers. agnostics and staging, according to current clinical practice guidelines, are serum creatinine concentration $\left(\mathrm{P}_{\mathrm{Cr}}\right)$ elevation and decline of urine output [2]. These criteria are also used for AKI diagnostics in patients undergoing hematopoietic stem cell transplantation (HSCT) [9,18]. However, fluctuations of $\mathrm{P}_{\mathrm{Cr}}$ and urine output, reflecting development of AKI, are not reliable markers of earlier, potentially reversible stages of tubular damage in patients following $\operatorname{HSCT}[4,8,12]$. 
Noteworthy, a series of molecular events are associated with tubular epithelium damage and subsequent kidney dysfunction. These alterations occur in still viable cells and may be applied either for the evaluation of early subclinical tubular injury or for the prediction of AKI development $[3,19,22]$. Both resident kidney cells and local immune cells are shown to enhance expression of some molecules, which may serve as biomarkers of early organ damage with still normal glomerular filtration rate (GFR) and $\mathrm{P}_{\mathrm{Cr}}$ values $[19,20,22]$. The efficacy of MBMs evaluation for the prediction of some etiological AKI variants has been already demonstrated $[5,6$, $13,21]$. There are, however, only scarce data concerning AKI associated with HSCT [17].
The aims of present study were as follows: a) to define AKI incidence with routine clinical criteria and the occurrence of subclinical tubular injury on the basis of MBMs assessment following HSCT b) to evaluate the efficacy of MBMs measurement for the prediction of AKI.

\section{Patients and Methods}

\section{Study design}

Ninety HSCT recipients who underwent allogeneic HSCT (46 males, 44 females) were enrolled into the observational prospective study. None of them had a history of renal disorders. Main clinical and demographic parameters of the group are presented in Table 1 .

Table 1.Patient Characteristics at Baseline $(\mathrm{n}=90)$

\begin{tabular}{|l|l|}
\hline Variables & No. of patients (\%)/M \pm SD \\
\hline Gender (F/M) & $44 / 46(49 / 51)$ \\
\hline Mean age, years & $33.8 \pm 11.9$ \\
\hline Conditioning regimen (MA/RIC) & $26 / 64(29 / 71)$ \\
\hline Primary diagnosis: & $7(8)$ \\
LH & $37(41)$ \\
AML & $22(25)$ \\
ALL & $9(10)$ \\
MDS & $9(10)$ \\
CML & $6(6)$ \\
\hline Others & $56 / 34(62 / 38)$ \\
\hline Remission state (yes/no) & $37(41)$ \\
Full remission & $19(21)$ \\
\hline Incomplete remission & \\
\hline HLA compatibility: & $66(73.3)$ \\
Complete & $24(26.7)$ \\
\hline Incomplete & \\
\hline Donor sex: & $68(75.6)$ \\
\hline Male & $22(24.4)$ \\
\hline Female & $3 / 86(3.5 / 96.5)$ \\
\hline Previous HSCT (yes/no) & $14 / 76(15.6 / 84.4)$ \\
\hline Hypertension at baseline (yes/no) & $94.9 \pm 23.5$ \\
\hline eGFR before HSCT, ml/min/1.73 M² & $6.3 \pm 5.6$ \\
\hline Number of pretransplantation chemotherapy courses & \\
\hline
\end{tabular}

Note: MAC, myeloablative conditioning regimen; RIC, reduced-intensity conditioning regimen; LH, Hodgkin lymphoma; AML, acute myeloblastic leukemia; ALL, acute lymphoblastic leukemia; MDS, myelodysplastic syndrome; CML, chronic myeloid leukemia; NHL, non-Hodgkin lymphoma; HLA, human leucocyte antigen; HSCT, hematopoietic stem cell transplantation; eGFR, estimated glomerular filtration rate; SD, standard deviation

The duration of follow up period was 6 weeks including week 0 (before conditioning and HSCT), and weeks 1 to 5 post-transplant. A weekly clinical examination included the following: arterial blood pressure measurements, diurnal fluid uptake $\left(\Sigma \mathrm{V}_{\text {fluid }}\right)$, signs of mucositis, clinically significant infections (both local and systemic), acute graft-versus-host disease (aGVHD). Appliance of drugs with known nephrotoxic side effects (chemotherapeutic agents, CNI, antimy- cotics, antibiotics and antivirals) [16] was also monitored on each week. Over observational period, all the patients underwent routine monitoring of serum creatinine $\left(\mathrm{P}_{\mathrm{Cr}}\right)$, alanine aminotransferase (ALT), albumin, lactate dehydrogenase $(\mathrm{LDH})$, hemoglobin $(\mathrm{Hb})$ as well as total $\mathrm{RBC}$ and leucocyte counts. AKI assessment and severity stratification was performed according to the KDIGO Guidelines (Kidney Disease Improving Global Outcomes, 2012) [9]. 


\section{Biomarker assays}

Urine samples were collected according to a standard procedure in the morning time, followed by centrifugation at 1500 $\mathrm{rpm}$ for $10 \mathrm{~min}$. The supernates were aliquoted and stored at $-80{ }^{\circ} \mathrm{C}$ until laboratory testing. Concentrations of urinary molecular biomarkers (MBM) were measured weekly in the urine specimens: calbindin, clusterin, IL-18 (interleukin-18), KIM-1 (kidney injury molecule-1), GST- $\pi$ (glutathione S-transferase- $\pi$ ) and MCP-1 (monocyte chemoattractant protein-1). Quantitative determination was performed with customized immunoassay kits using a Bio-Plex 200 analyzer (Bio-Rad Lab, Inc., USA). The MBM concentrations per sample were normalized for serum creatinine level in the given sample. Control group included thirty-three age- and gender-matched healthy volunteers.

Increased MBM level on week 0 was defined as MBM concentration exceeding upper limit of $95 \%$ CI for the control group. Elevation of MBM at the weeks 1 to 5 was determined when concentration on subsequent week increased 2-fold or more compared to MBM concentration at week 0 , or previous week.

\section{Statistics}

Statistical analysis was performed with a licensed software package (SAS 9.4). Each observation time-point was included into analysis as a single case, with exception of censored observations (474 cases in total). For a comparative inter-group analysis, a one way dispersion analysis (ANOVA) was applied. Multiple linear regression was used to find correlations between the MBM values and continuous variables, e.g., Pcr. A multivariate logistic regression analysis was applied to assess predictive value of MBMs in which the MBMs were included as independent variables, along with other potential confounders. The data are presented as a $\mathrm{M} \pm \mathrm{SD}$, median with interquartile ranges [m (25-75\%)], mean values, and 95\% confidence interval (95\% CI) for a mean value, as well as $\mathrm{M} \pm \mathrm{SEM}$. Any intergroup differences or regression coefficients (in multivariate analysis) were considered significant by $\mathrm{p}<0.05$.

\section{Results}

Incidence of AKI cases as assessed by KDIGO criteria (stage 1 to 3), was found to be increased early post-transplant, with a maximum frequency by the week 5. (Fig. 1). In parallel, a regular trend was noted for the $\mathrm{P}_{\mathrm{Cr}}$ increment; however, the 95\% CI values still remained within normal limits.

Meanwhile, percentage of cases with increased MBM levels in urine sufficiently exceeded the AKI occurrence. The median of simultaneously increased MBMs was 3 (2 to 5) over the total observation period, with only minimal variations at different weeks (Table 2). For the most MBMs, urinary excretion exhibited a several-fold increase post-transplant, as compared to controls. Noteworthy, concentrations of the most MBMs before HSCT were higher than those in the control group (Fig. 2).

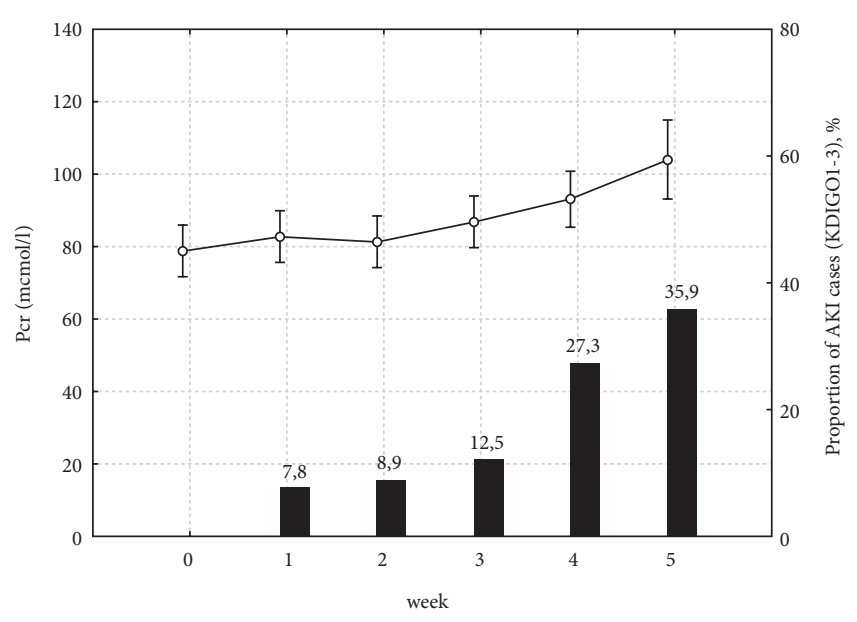

Figure 1. Proportion of AKI cases (KDIGO 1-3) (bars) and $\mathrm{P}_{\mathrm{cr}}$ in the post-translant period

Note: AKI, acute kidney injury; $\mathrm{P}_{\mathrm{Cr}}$, serum creatinine concentration, (mcmol/L); KDIGO, Kidney Disease Improving Global Outcomes (stage 1 to 3 )

Table 2. Frequency of cases with increased molecular biomarkers at different weeks post-HSCT, \% of total

\begin{tabular}{|l|l|l|l|l|l|l|l|}
\hline $\begin{array}{l}\text { Week post- } \\
\text { HSCT }\end{array}$ & Calbindin,\% & Clusterin, \% & GST- $\pi_{1} \%$ & IL-18, \% & KIM-1, \% & MCP-1, \% & $\begin{array}{l}\text { NMBM, } \\
\text { m (25-75\%) }\end{array}$ \\
\hline 0 & 16.7 & 70.4 & 66.7 & 24.1 & 38.9 & 44.4 & $3(1 ; 3)$ \\
\hline 1 & 32.4 & 89.7 & 91.2 & 30.9 & 58.8 & 48.5 & $3(2 ; 5)$ \\
\hline 2 & 42.6 & 86.8 & 88.2 & 32.4 & 60.3 & 50.0 & $4(2 ; 5)$ \\
\hline 3 & 30.0 & 90.0 & 78.6 & 28.6 & 67.1 & 58.6 & $4(2 ; 5)$ \\
\hline 4 & 23.5 & 92.6 & 86.8 & 23.5 & 60.3 & 70.6 & $3(3 ; 4)$ \\
\hline 5 & 46.9 & 96.9 & 90.6 & 34.4 & 62.5 & 93.8 & $4(4 ; 5)$ \\
\hline
\end{tabular}

Note. GST- $\pi$ - glutathione-S-transferase ( $\pi$ class); IL-18, Interleukin-18; KIM-1,kidney injury molecule1; MCP-1, monocyte chemoattractant protein 1; NMBM - median of increased MBM number 
Clusterin, MCP-1, and KIM-1 levels showed direct significant and independent correlations with $\mathrm{P}_{\mathrm{Cr}}$ in multiple linear regression models adjusted for other important clinical factors (Table 3). IL-18 excretion negatively correlated with $\mathrm{P}_{\mathrm{Cr}}$ levels registered at the subsequent week. Increase of KIM-1 and/or MCP-1 levels was found to be the independent pre-
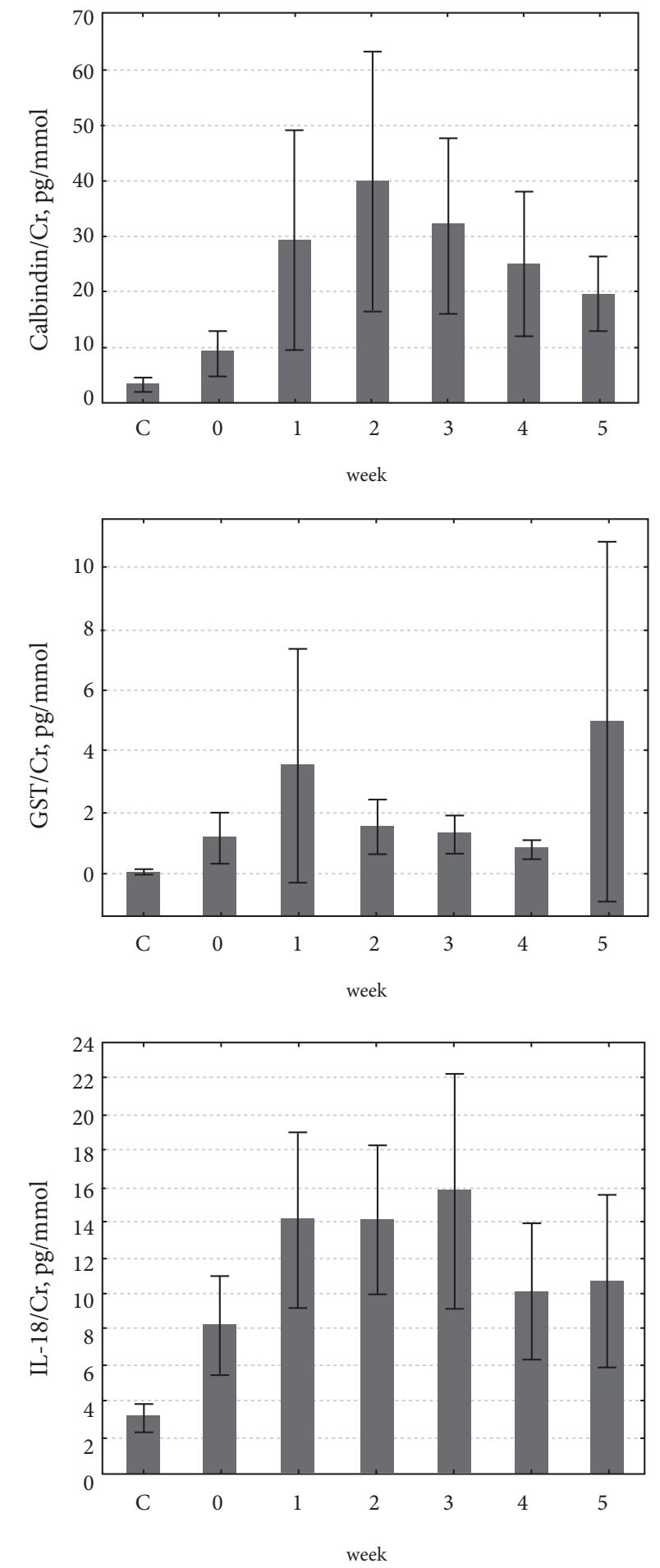

dictor of AKI at a week following the MBM assessment (Table 4). Relative risk for AKI increased 2.3-fold in case of KIM-1 or MCP-1 elevation, while 3.4-fold increase in RR was found when both MBMs (KIM-1 and MCP-1) were elevated. Other MBMs studied did not have any associations with AKI risk, neither separately, nor in combinations.
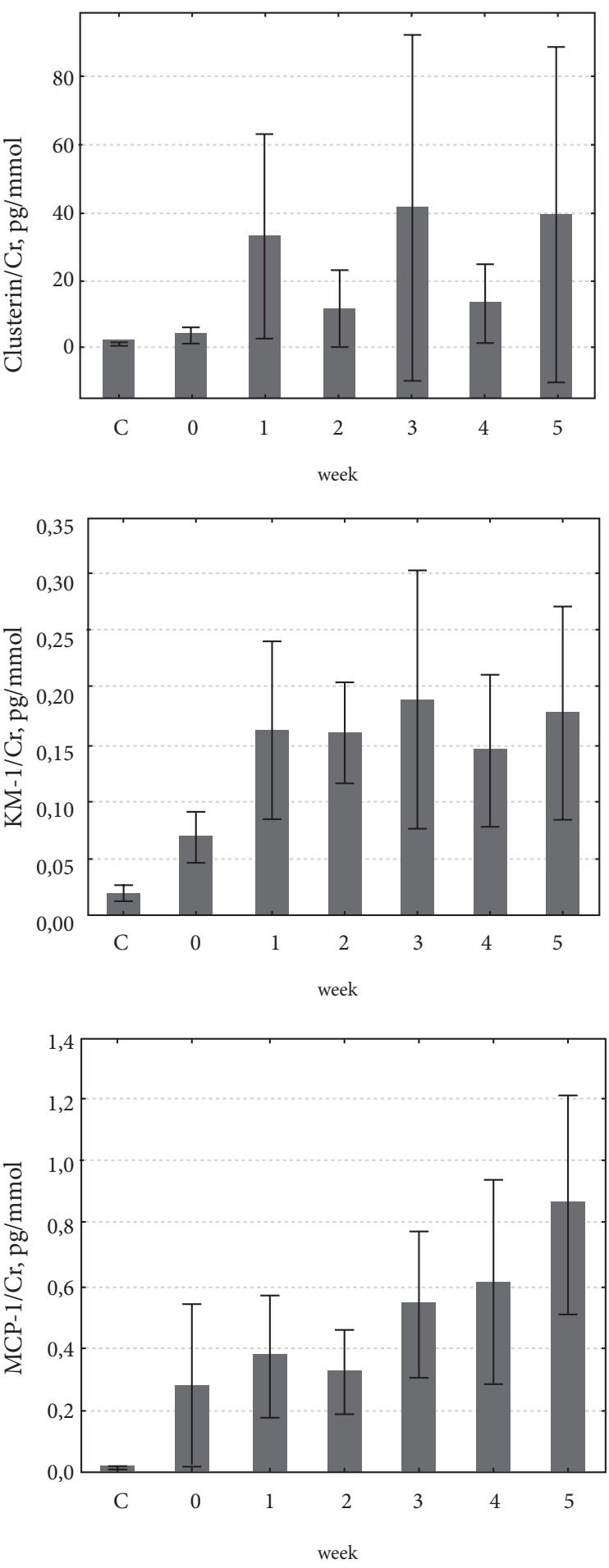

Figure 2. Urinary biomarker concentrations in early post-transplant period*.

Note: Calbindin/Cr, urinary calbindin/creatinine ratio; Clusterin/Cr, urinary clusterin/creatinine ratio; IL-18/Cr, urinary interleukin-18/creatinine ratio; KIM-1/Cr, urinary KIM-1/creatinine ratio; GST- $\pi / \mathrm{Cr}$-urinary glutathione-S-transferase ( $\pi$ class)/creatinine ratio; Monocyte chemoattractant protein-1/Cr, urinary Monocyte chemoattractant protein-1/creatinine ratio; C, control group 
Table 3. Correlations between the biomarkers and $\mathrm{P}_{\mathrm{Cr}}$ values*

\begin{tabular}{|l|l|l|l|}
\hline Dependent variable & Biomarker & Beta \pm SEM & $\mathrm{p}$ \\
\hline \multirow{4}{*}{$\mathrm{P}_{\mathrm{Gr}}$ a week after MBM analysis } & Clusterin & $0.162 \pm 0.057$ & 0.005 \\
\cline { 2 - 4 } & $\mathrm{MCP}-1$ & $0.194 \pm 0.058$ & 0.001 \\
\cline { 2 - 4 } & $\mathrm{KIM}-1$ & $0.153 \pm 0.057$ & 0.008 \\
\cline { 2 - 4 } & $\mathrm{IL}-18$ & $-0.143 \pm 0.056$ & 0.012 \\
\hline Absolute $P_{\mathrm{Cr}}$ increase against previous week results & Clusterin & $0.348 \pm 0.057$ & $<0.001$ \\
\cline { 2 - 4 } & MCP-1 & $0.185 \pm 0.061$ & 0.002 \\
\cline { 2 - 4 } & KIM-1 & $0.135 \pm 0.060$ & 0.026 \\
\hline Absolute $P_{\mathrm{Gr}}$ increase against (pre-HSCT) values (week 0) & Clusterin & $0.351 \pm 0.057$ & $<0.001$ \\
\cline { 2 - 4 } & MCP-1 & $0.372 \pm 0.057$ & $<0.001$ \\
\cline { 2 - 4 } & KIM-1 & $0.149 \pm 0.060$ & 0.014 \\
\hline
\end{tabular}

* - The data are obtained by multiple linear regression analyses adjusted for: patients' age; gender; syst.BP; diast.BP; $\Sigma \mathrm{V}_{\text {fluid; }}$ hemoglobin levels; leukocyte counts; RBC counts; serum albumin; ALT, LDH; mucositis grade (0 to 3); infections (0, absent; 1, local infection; 2, systemic infection); aGVHD (yes/no); number of nephrotoxic drugs applied (n)

Note. MCP-1, monocyte chemoattractant protein 1; KIM-1, kidney injury molecule 1; IL-18, interleukin 18; $\mathrm{P}_{\mathrm{Cr}}$, serum creatinine concentration; syst. BP, systolic blood pressure; diast. BP, diastolic blood pressure; $\Sigma \mathrm{V}_{\text {fluid, }}$ total daily fluid intake; ALT, alanineaminotransferase; LDH, lactate dehydrogenase; aGVHD, acute graft-versus-host disease.

Table 4. Independent predictors of AKI (multivariate logistic regression analysis with stepwise backward exclusion of variables*)

\begin{tabular}{|l|l|l|l|l|l|}
\hline $\begin{array}{l}\text { Variables } \\
\text { (arb.units) }\end{array}$ & $\mathrm{B} \pm \mathrm{SD}$ & Wald statistic & $\mathrm{p}$ & $\operatorname{Exp}(\beta)$ & $95 \% \mathrm{Cl}$ for $\operatorname{Exp}(\beta)$ \\
\hline $\mathrm{KIM} / \mathrm{MCP}(0-1-2)$ & & & & \\
$\mathrm{KIM} / \mathrm{MCP}(1)$ & $0.819 \pm 0.392$ & 4.3374 & 0.006 & & \\
$\mathrm{KIM} / \mathrm{MCP}(2)$ & $1.212 \pm 0.378$ & 10.273 & 0.036 & 2.269 & $1.053-4.892$ \\
\hline Mean blood pressure, $\mathrm{mm} \mathrm{Hg}$ & $0.025 \pm 0.012$ & 4.513 & 0.001 & 3.361 & $1.602-7.054$ \\
\hline$\Sigma \mathrm{V}_{\text {fluid' }} \mathrm{L}$ & $-0.335 \pm 0.101$ & 11.068 & 0.034 & 1.025 & $1.002-1.048$ \\
\hline Hemoglobin, g/L & $-0.019 \pm 0.008$ & 6.180 & 0.001 & 0.716 & $0.587-0.871$ \\
\hline Leukocytes, $\times 10^{9} / \mathrm{L}$ & $0.096 \pm 0.049$ & 3.873 & 0.013 & 0.981 & $0.966-0.996$ \\
\hline
\end{tabular}

Variables included at step 1: patients' age, gender, $\mathrm{P}_{\mathrm{Cr}}$ conditioning intensity, $\Sigma \mathrm{V}_{\text {fluid }}$, hemoglobin levels, leukocytes, ALT, mucositis (grade 1 to 3), aGVHD (yes/no), number of nephrotoxic drugs applied (n), KIM/MCP, mean blood pressure.

Note: abbreviations as for Table 3

\section{Discussion}

AKI is a common complication of an early posttransplant period, which correlates with inferior short- and long-term outcomes of HSCT $[11,15]$. A special feature of HSCT-associated renal dysfunction is a simultaneous action of multiple renotoxic factors including (but not limited to) nephrotoxic drugs, alterations of systemic circulation, infections, immune suppression, thus enabling different and complex mechanisms of tubular epithelium damage. Massive infusion therapy, drug-enhanced tubular secretion, body mass losses may contribute to low efficiency of routine AKI criteria in patients following HSCT [11]. Some existing data presume potential clinical value of molecular markers, expressed by resident renal cells and local immune cell populations in certain types of kidney damage $[5,6,13,19$ 21]. Meanwhile, only scattered publications deal with comparative analysis of different MBMs in AKI following HSCT [17].

Unlike moderate $\mathrm{P}_{\mathrm{Cr}}$ changes, the MBMs under study exhibited a marked increase which clearly preceded the emerging AKI. 
Incidence of cases with increased MBMs significantly exceeded the incidence of AKI post-transplant. Moreover, based on these data one can presume that sub-clinical tubular damage affects the majority of patients in the setting of HSCT. Notably, simultaneous elevation of different MBMs found in our study may, probably, reflect different renal responses to multiple damaging factors following HSCT.

The results obtained with MBM panel are definitely in line with basic concept of consequences of acute kidney injury $[3,19]$. In particular, this concept allows to discriminate two principal stages of cellular response: (1) an initial stage, when damaged resident tubular epithelial cells retain viability followed by (2) a phase of cellular death and subsequent renal dysfunction, i.e., AKI [19]. Study results have clearly shown that increased MBM levels anticipate Pcr increment and, thus, may define the subclinical kidney damage. Higher occurrence of increased MBMs as compared to increase of Pcr make it clear that tubular epithelial damage not always results in clinically significant renal dysfunction defined as AKI.

One may suggest that the imbalance of various adaptation mechanisms is significant for AKI development. Some of cellular molecular adaptation mechanisms are associated with unfavorable events causing apoptosis/necroptosis, whereas others may induce physiological responses oriented towards cell survival. In particular, increased levels of urinary KIM-1 and MCP-1, being inflammatory molecules, are significantly and independently associated with Pcr changes and higher risk of subsequent AKI. Meanwhile, the overall increase of clusterin, calbindin and GST- $\pi$ excretion did not correlate with AKI development. One may, therefore, suggest that their higher secretion by viable tubular epithelium could reflect a physiologic response to the damaging factors. Moreover, IL-18 showed even a negative correlation with Pcr, thus pointing to probable association between its up-regulation and protective mechanisms within tubular epithelium in HSCT patients $[1,10]$.

Hence, we have shown that multiple nephrotoxic effects early after HSCT commonly result in markedly increased urinary excretion of distinct molecular biomarkers, reflecting subclinical tubular injury in the absence of AKI criteria. The subsequent development of clinical AKI can be predicted by means of KIM-1 and MCP-1 urinary excretion evaluation.

\section{Conflict of interests}

No conflict of interests is declared.

The study was performed under financial support of the Committee for Science and Higher School of the St. Petersburg Government and The First St. Petersburg I. Pavlov State Medical University (Contest of innovative research projects - 2015).

\section{References}

1. Alnasser HA, Guan Q, Zhang F, Gleave ME, Nguan CY, Du C. Requirment of clusterin expression for prosurvival autophagy in hypoxic kidney tubular epithelial cells. Am J Physiol Renal Physiol 2016; 310 (2): F160-73.
2. Bellomo R, Kellum JA, Ronco C. Defining acute renal failure: physiological principles. Intensive Care Med 2004, 30 (1): 33-37.

3. Basile DP, Anderson MD, Sutton TA. Pathophysiology of acute kidney injury. Compr Physiol. 2012; 2 (2): 1303-1353.

4. Coca SG, Parikh CR. Urinary biomarkers for acute kidney injury: perspectives on translation. Clin J Am Soc Nephrol 2008; 3 (2): 481-490.

5. Field M, Dronovalli V, Mistry P Drayson M, Ready A, Cobbold $\mathrm{M}$, Inston $\mathrm{N}$. Urinary biomarkers of acute kidney injury in diceased organ donors-kidney injury molecule- 1 as an adjunct to predicting outcome. Clin Transplant 2014; 28 (7): 808-815.

6. Ghatanatti R, Teli A, Tirkey SS Bhattacharya S, Sengupta G, Mondal A. Role of renal biomarkers as predictors of acute kidney injury in cardiac surgery. Asian Cardiovasc Thorac Ann 2014; 22 (2): 234-241.

7. Haase M, Kellum JA, Ronco C. Subclinical AKI - an emerging syndrome with important consequences. Nat Rev Nephrol 2012, 8 (12): 735-739.

8. Hjortrup PB, Haase N Wetterslev M, Perner A.Clinical review: Predictive value of neutrophil gelatinase-associated lipocalin for acute kidney injury in intensive care patients. Critical Care. 2013, 17 (2): 211

9. Kellum JA, Aspelin P, Barsoum RS et al. KDIGO Clinical Practice Guideline for Acute Kidney Injury. Kidney Int (Suppl.) 2012; (2): 1.

10. Kuwata K, Nakamura I, Ide M, Sato H, Nishikawa S, Tanaka M. Comparison of changes in urinary and blood levels of biomarkers associated with proximal tubular injury in rat models. J Toxicol Pathol 2015; 28 (3): 151-164.

11. Lopes JA, Jorge S Acute kidney injury following HCT: incidence, risk factors and outcome. Bone Marrow Transplant 2011; 46 (11): 1399-1408.

12. Martensson J, Martling CR, Bell M Novel Biomarkers of acute kidney injury and failure: clinical applicability. $\mathrm{Br} \mathrm{J}$ Anaesth 2012; 109 (6): 843-850.

13. Menzorov MV, Shutov AM, Makeeva ER, Mikhailova EV, Parfenova EA The role of neutrophil gelatinase-associated lipocalin for the early prediction of acute kidney injury in patients with acute coronary syndrome. Fundamental'nye issledovaniya. 2013; 9 (4): 698-702. (In Russian)

14. Metzger J, Kirsch T, Schiffer E Ulger P, Mentes E, Brand K, Weissinger EM, Haubitz M, Mischak H, Herget-Rosenthal S. Urinary excretion of twenty peptides forms an early and accurate diagnostic pattern of acute kidney injury. Kidney Int 2010; 78 (12): 1252-1262.

15. Sawinski D. The kidney effects of hematopoietic stem cell transplantation. Adv Chronic Kidney Dis 2014;21(1):96-105.

16. Schrier RW, Coffman TM, Falk RJ, Molitoris BA, Neilson EG. In: Schrier's Diseases of the Kidney 2013; 868-1086.

17. Shingai N, Morito T. Urinary liver-type fatty acid-binding protein linked with increased risk of acute kidney injury after allogeneic stem cell transplantation. Biol Blood Marrow Transplant 2014; 20 (12): 2010-2014. 
18. Smirnov AV, Dobronravov VA, Rumyantsev AS, Shilov EM, Vatazin AV et al. National guidelines acute kidney injury: basic principles of diagnosis, prevention and therapy. Part 1. Nefrologija. 2016, 20 (1): 79-104. (In Russian)

19. Smirnov AV, Dobronravov VA, Rumyantsev AS, Kayukov IG. Acute kidney injury. M.: MIA Publishers 2015: 30-79. (In Russian)

20. Smirnov AV, Kayukov IG, Dobronravov VA, Kucher AG. Acute kidney injury and acute renal failure: some lessons from international initiatives. Nefrologija. 2008; 12 (3): 7-12. (In Russian)
21. Soni SS, Cruz D, Bobek I. NGAL: a biomarker of acute kidney injury and other systemic conditions. Int Urol Nephrol 2010; 42 (1): 141-150.

22. Vaidya VS, Ferguson MA, Bonventre JV. Biomarkers of acute kidney injury. Annu Rev Pharmacol Toxicol. 2008; 48: 463-493.

23. Zeng X, McMahon GM, Brunelli SM, Bates DW, Waikar SS.Incidence, outcomes, and comparisons across definitions of AKI in hospitalized individuals. Clin J Am Soc Nephrol. 2014, 9 (1): 12-20.

\section{Субклиническая альтерация тубулярного эпителия и острое повреждение почек при аллогенной трансплантации гемопоэтических стволовых клеток}

Владимир А. Добронравов ${ }^{1,2}$, Кирилл А. Смирнов ${ }^{1,2}$, Борис В. Афанасьев ${ }^{1,3}$, Ольга В. Галкина ${ }^{1,2}$, Алексей В. Смирнов $^{1}$ ${ }^{1}$ Первый Санкт-Петербургский государственный медицинский университет им. акад. И. П. Павлова, Россия ${ }^{2}$ Научно-исследовательский институт нефрологии

${ }^{3}$ Научно-исследовательский институт детской онкологии, гематологии и трансплантологии им. Р. М. Горбачевой

\section{Резюме}

\section{ЦЕЛЬ ИССЛЕДОВАНИЯ}

определение значения молекулярных биомаркеров (МБМ), ассоциированных с альтерацией клеток тубулярного эпителия, в прогнозировании острого повреждения почек после трансплантации гемопоэтических стволовых клеток (ТГСК).

\section{ПАЦИЕНТЫ И МЕТОДЫ}

В открытое обзервационное проспективное исследование включены 90 больных (46 мужчин и 44 женщины), которым была выполнена ТГСК. В образцах мочи до ТГСК и на пяти первых неделях раннего посттрансплантационного периода определены концентрации МБМ (кальбиндина, кластерина, интерлейкина-18 (IL-18), молекулы повреждения почек-1 (KIM-1), глютатион-S-трансферазы (л-класc) (GST- $\pi$ ), протеина хемотаксиса моноцитов-1 (МСР-1). Параллельно мониторировали основные клинические показатели. Диагностику и стратификацию тяжести острого повреждения почек (ОПП) проводили согласно рекомендациям KDIGO (Kidney Disease Improving Global Outcomes).

\section{РЕЗУЛЬТАТЫ}

Доля случаев с ОПП прогрессивно увеличивалась в раннем посттрансплантационном периоде, достиг- нув максимума к неделе 5 после ТГСК. Повышение содержания МБМ выявляли существенно чаще случаев ОПП, причем повышение МБМ предшествовало формированию дисфункции почек (ОПП). При множественном регрессионном анализе кластерин, MCР-1 и КІМ-1 имели прямую, достоверную, независимую от других анализируемых факторов связь с креатинином сыворотки крови на неделе, следующей за определением МБМ. Повышение мочевой экскреции KIM-1 и (или) MCР-1 было независимо от других клинических факторов ассоциировано с увеличением относительного риска $(\mathrm{OP})$ развития ОПП.

\section{ЗАКЛЮЧЕНИЕ}

Множественные ренотоксичные воздействия при ТГСК приводят к существенному и одновременному повышению экскреции с мочой БМ тубулярного повреждения, отражающему субклиническое повреждение клеток тубулярного эпителия в отсутствии критериев ОПП; оценка мочевой экскреции KIM-1 и MCР-1 представляется наиболее подходящим методом предиктивной диагностики ОПП ассоциированного с ТГСК.

\section{Ключевые слова}

Острое повреждение почек, трансплантация гемопоэтических стволовых клеток, биомаркеры. 